\title{
Body size reduction under starvation, and the point of no return, in ephyrae of the moon jellyfish Aurelia aurita
}

\author{
Zhilu Fu ${ }^{1}$, Masashi Shibata ${ }^{1}$, Ryosuke Makabe ${ }^{2}$, Hideki Ikeda ${ }^{1}$, Shin-ichi Uye ${ }^{1, *}$ \\ ${ }^{1}$ Graduate School of Biosphere Science, Hiroshima University, 4-4 Kagamiyama 1 Chome, Higashi-Hiroshima 739-8528, Japan \\ ${ }^{2}$ Faculty of Science and Engineering, Ishinomaki Senshu University, 1 Shinmito Minamisakai, Ishinomaki 986-8580, Japan
}

\begin{abstract}
Scyphozoan ephyrae need to start feeding before their endogenous nutritional reserves run out, and the success of feeding and growth is crucial to their recruitment into the medusa population. To evaluate starvation resistance in first-feeding ephyrae of the moon jellyfish Aurelia aurita s.l., we determined their point of no return $\left(\mathrm{PNR}_{50}\right)$, i.e. days of starvation after which $50 \%$ of ephyrae die even if they then feed. $\mathrm{PNR}_{50}$ values were $33.8,38.4$ and $58.6 \mathrm{~d}$ at 15 , 12 and $9^{\circ} \mathrm{C}$, respectively. Before reaching $\mathrm{PNR}_{50}$, the ephyrae showed significant body size reduction: ca. 30 and $50 \%$ decrease in disc diameter and carbon content, respectively. These PNR $_{50}$ values are nearly 1 order of magnitude longer than those of larval marine molluscs, crustaceans and fishes, which is attributable to the ephyra's extremely low metabolic (i.e. respiration) rate relative to its copious carbon reserves. Such a strong endurance under prolonged starvation is likely an adaptive strategy for $A$. aurita ephyrae, the release of which is programmed to occur during the annual period of lowest temperatures, allowing them to cope with the concomitant seasonal food scarcity. Future studies are needed to identify causes of death for wild ephyrae, which are prone to starvation and/or predation, to forecast outbreaks prior to the season of medusa blooms.
\end{abstract}

KEY WORDS: Jellyfish bloom $\cdot$ Mortality $\cdot$ Population dynamics $\cdot$ Predation $\cdot$ Starvation Resale or republication not permitted without written consent of the publisher

\section{INTRODUCTION}

Scyphozoan jellyfish provide a variety of beneficial ecosystem services (e.g. food for humans, source of useful compounds for humans, carbon sequestration, nutrient regeneration), but their massive blooms have often been reported as degrading marine ecosystem services (see Doyle et al. 2014, Lucas et al. 2014 for reviews). Among bloom-forming scyphozoans, Aurelia aurita s.l. is the most common in temperate coastal waters around the world, and mass occurrences of this species have been reported from various regions (Richardson et al. 2009, Purcell 2012, Condon et al. 2013). Dense aggregations of A. aurita not only are destructive to fishery industries (Graham 2001, Uye \& Ueta 2004) but also cause serious problems for coastal power plant operation (Purcell et al.
2007, Dong et al. 2010). In addition, blooms of $A$. aurita have considerable impacts on the marine food chain, since the medusae compete for zooplankton with planktivorous fishes and eat fish eggs and larvae (Olesen 1995, Purcell 1997, Hansson et al. 2005), which implies that the greater the prevalence of jellyfish, the more fish stocks would be reduced (Parsons \& Lalli 2002, Lynam et al. 2006, Uye 2011). Hence, it is important to specify the causes for enhancement of jellyfish populations, to forecast likely outbreaks prior to the season of medusa blooms and to develop countermeasures to alleviate the damage.

There are essentially 2 biological factors that affect the size of medusa populations: (1) the abundance of benthic polyps, which reproduce asexually and undergo seasonal strobilation to release planktonic 
ephyrae, and (2) the mortality of ephyrae before recruitment to the medusa stage. Much knowledge has been accumulated about polyp stocks in previous studies; among various environmental factors, an increase in temperature (i.e. global warming), food supply (i.e. eutrophication) and/or artificial structures with overhanging surfaces accelerates the polyp asexual reproduction rate, thus boosting polyp populations (Han \& Uye 2010, Lucas et al. 2012, Duarte et al. 2013). In contrast, no studies have been conducted concerning the mortality of ephyrae, except for a preliminary study by Ishii et al. (2004) of A. aurita in Tokyo Bay, where approximately $99 \%$ of the newly released ephyrae die before they become young medusae. However, the causes for such high mortality remained largely unidentified.

For development to the medusa stage, ephyrae must start feeding before their nutritional reserves derived from the parent polyps run out. However, ephyrae are inefficient feeders compared to medusae, because they lack the bell structure and generate only a small vortex of feeding current (Costello \& Colin 1994, Sullivan et al. 1997), and their narrow tube-like manubrium is less effective than a medusa's 4-branched oral arms. In addition, the release of ephyrae from strobilating A. aurita polyps usually takes place during winter and early spring (Toyokawa et al. 2000, Lucas 2001), when biomass and the production of their food (i.e. micro- and mesozooplankton) are the lowest. Therefore, we hypothesized that starvation is a primary factor accounting for the mortality of $A$. aurita ephyrae. To assess this working hypothesis, we conducted laboratory experiments to examine the effect of starvation on the survival of $A$. aurita ephyrae, and their capability to recover from starvation and then develop to advanced stages. We determined their point of no return (PNR) from starvation and discussed starvation and other factors as possible determinants of the mortality of ephyrae.

\section{MATERIALS AND METHODS}

\section{Stock culture of polyps}

Ephyrae of Aurelia aurita were obtained from stock cultures of polyps derived from matured medusae in the Inland Sea of Japan in the summer of 2010. The stock cultures were maintained in plastic containers (diameter: $150 \mathrm{~mm}$, depth: $65 \mathrm{~mm}$ ) containing ca. $1 \mathrm{l}$ of filtered $(0.2 \mu \mathrm{m})$ seawater at a salinity of 32 and held at $25^{\circ} \mathrm{C}$ in darkness. The polyps were fed ad libitum for 3-4 h with newly hatched Artemia sp. nauplii once or twice weekly, followed by replacement of the seawater.

\section{Starvation experiment}

The stock-cultured polyps were transferred to $14^{\circ} \mathrm{C}$ to induce strobilation and release of ephyrae (see Kakinuma 1962, Han \& Uye 2010). Newly released ephyrae ( $<24 \mathrm{~h}$ old) were placed individually in wells of 6 -well polystyrene culture plates containing $10 \mathrm{ml}$ of the filtered seawater (salinity 32). A total of 250, 220 and 260 ephyrae were kept in darkness at 9, 12 and $15^{\circ} \mathrm{C}$, respectively, in thermostatically controlled incubators. Seawater in the wells was replaced every second day.

Ten randomly selected ephyrae from each temperature were taken every $2 \mathrm{~d}$, placed individually (manubrium side up) in a small glass container and photographed with a digital camera attached to a stereomicroscope. After being photographed, they were returned to their original wells or transferred to new plates for feeding (see next paragraph). Ephyrae morphometry was examined by measuring 5 dimensions to the nearest 0.01 to $0.02 \mathrm{~mm}$, in accordance with the method of Straehler-Pohl \& Jarms (2010): total body diameter (TBD), disc diameter (DD), central disc diameter (CDD), marginal lappet length

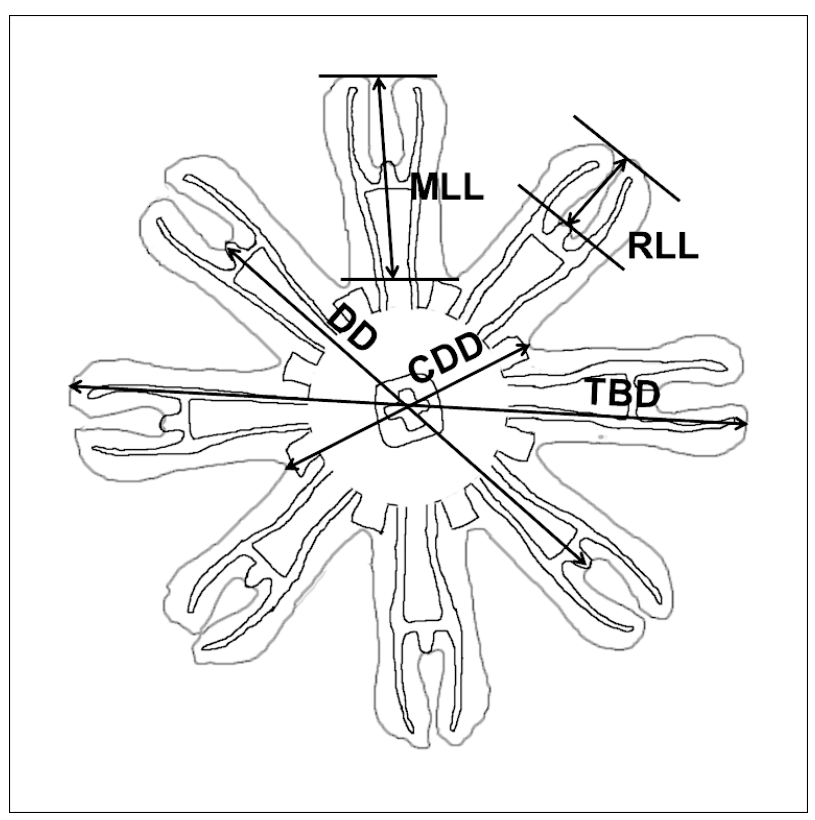

Fig. 1. Aurelia aurita ephyra showing measured dimensions. CDD: central disc diameter; DD: disc diameter; MLL: marginal lappet length; RLL: rhopalial lappet length; TBD: total body diameter 

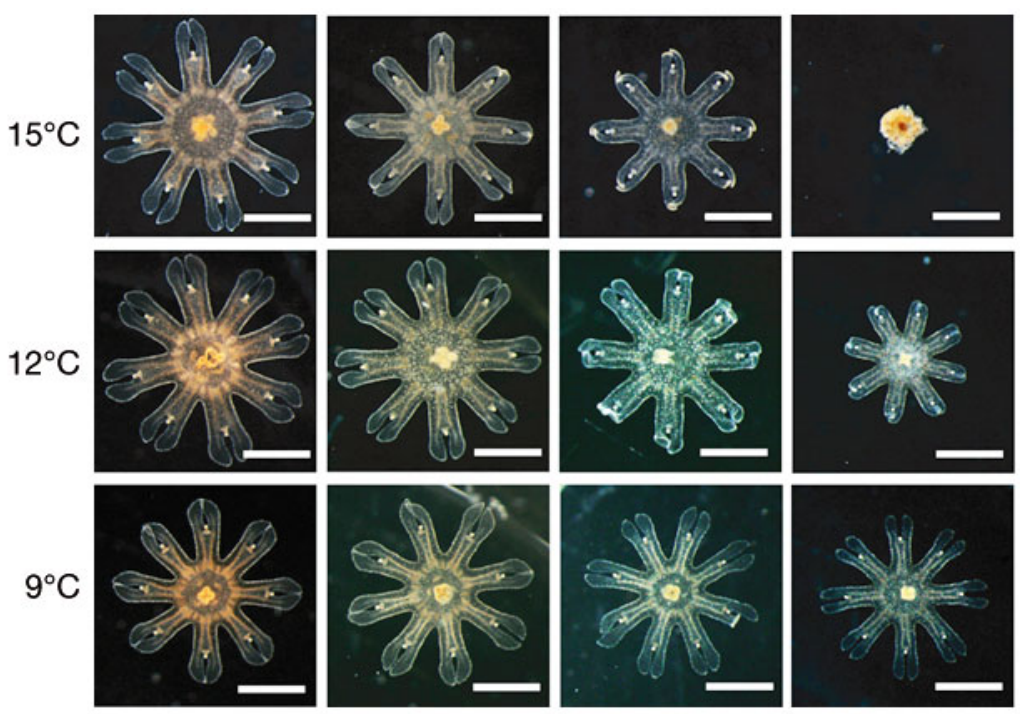

Day 0

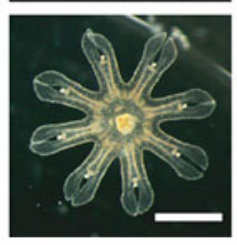

Day 10

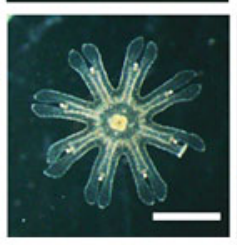

Day 30

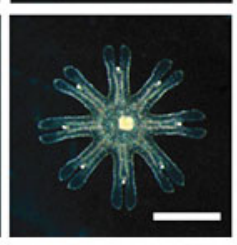

Day 50

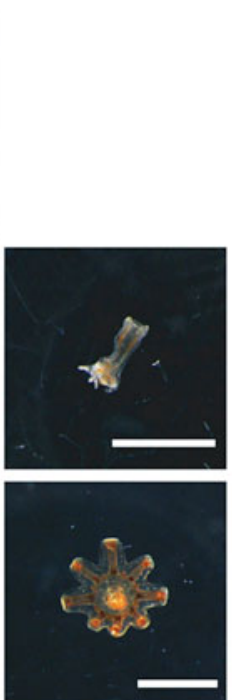

Day 80

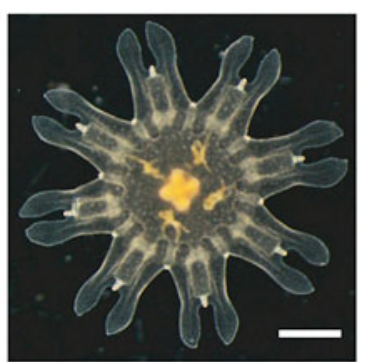

Advanced ephyra

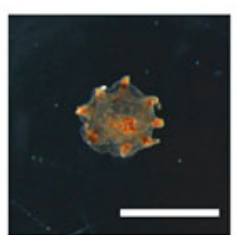

Day 100

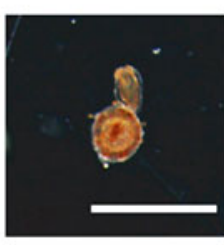

Day 130

Fig. 2. Morphological changes in Aurelia aurita ephyrae kept starved for various periods at 9, 12 and $15^{\circ} \mathrm{C}$. Days indicate duration of continuous starvation. An advanced ephyra is also shown. Scale bars $=1 \mathrm{~mm}$

(MLL) and rhopalial lappet length (RLL) (Fig. 1), using image-analysis software (Image J, National Institute of Health, USA).

Feeding was initiated for groups of 10 starved ephyrae per temperature group, at 2 to 4 d intervals for up to $84 \mathrm{~d}$, by introducing 20 newly hatched Artemia nauplii to their wells daily. After the ephyrae fed for ca. $6 \mathrm{~h}$, the remaining nauplii were removed, and the seawater was replaced. Fed ephyrae were monitored daily until they died off or grew to the advanced ephyrae stage, at which the adradial canal between the perradial canal and the interradial canal extends to the central disc margin (Fig. 2). Ephyrae showing no pulsation after several stirrings of the seawater with a pipette were judged to be dead.

The median longevity $\left(\mathrm{ML}_{50}\right)$ was determined as the duration of starvation at which $50 \%$ of ephyrae had died. The point of no return $\left(\mathrm{PNR}_{50}\right)$ was determined as the duration of starvation at which only $50 \%$ of ephyrae could recover from starvation and grow to the advanced ephyra stage.

\section{Measurements of carbon and nitrogen contents}

Nine lots, each consisting of approximately 600 ephyrae newly released from the stock-cultured polyps, were transferred to a glass container containing 51 of filtered seawater (salinity 32 ). Three containers were held at 9,12 and $15^{\circ} \mathrm{C}$ in darkness. The seawater was gently circulated by aeration $(15 \mathrm{ml}$ $\mathrm{min}^{-1}$ ) from a glass pipette to keep the ephyrae suspended. The seawater was replaced weekly.

At $10 \mathrm{~d}$ intervals, triplicate samples, each consisting of 20 to 110 ephyrae, were randomly picked up from each container, and at least 5 ephyrae from each sample were photographed under a stereomicroscope to measure DD. These specimens were placed onto a pre-combusted and preweighed GF/F glass-fiber filter (diameter: $25 \mathrm{~mm}$ ) and rinsed with $3 \%$ isotonic ammonium formate to remove external salts. The filter was then placed in a plastic case and dried in an electric oven (Tabai, LG-112) at $60^{\circ} \mathrm{C}$ for $24 \mathrm{~h}$, followed by placement in a desiccator for 3 to 5 mon until analysis. Dry weight was determined on a microbalance (Mettler Toledo, Type MT 5) to the nearest $0.1 \mu \mathrm{g}$, and carbon and nitrogen contents were analyzed with an elemental analyzer (PerkinElmer, 02400II CHNS).

\section{Statistical analysis}

To compare the mean values among different experiments, 1- or 2-way ANOVAs were used (SPSS 10.0 software). When the ANOVA results were significant $(p<0.05)$, Tukey's pair-wise comparisons were performed to ascertain the significance of differences between treatment means. 


\section{RESULTS}

\section{Morphological changes during starvation}

A series of morphological changes in ephyrae kept starved at 9,12 and $15^{\circ} \mathrm{C}$ is depicted in Fig. 2. Newly released ephyrae from strobilating polyps were reddish in body color. As starvation advanced, this reddish color gradually faded; at the same time, body diameter decreased and was accompanied by thinning and reduction of the marginal lappets. As starvation was prolonged further, the marginal lappets almost disappeared, and pulsations became less frequent. Finally, starved ephyrae became reduced to a rod-like oral core.

The morphological changes were slower at lower temperatures as demonstrated by the decrease in DD (Fig. 3). Mean DD was $2.3 \pm 0.04$ (SD) mm on Day 0, with no significant differences among the temperature groups (1-way ANOVA, p > 0.05). Mean DD on Day 50 were $1.18 \pm 0.06,1.58 \pm 0.19$ and $1.66 \pm$ $0.20 \mathrm{~mm}$ at 15,12 and $9^{\circ} \mathrm{C}$, respectively, and were significantly different among the groups (1-way ANOVA, $\mathrm{p}<0.01$ ). By fitting a linear regression, the overall decrease rate was greatest $\left(0.021 \mathrm{~mm} \mathrm{~d}^{-1}\right)$ at $15^{\circ} \mathrm{C}$, intermediate $\left(0.019 \mathrm{~mm} \mathrm{~d}^{-1}\right)$ at $12^{\circ} \mathrm{C}$ and lowest $\left(0.012 \mathrm{~mm} \mathrm{~d}^{-1}\right)$ at $9^{\circ} \mathrm{C}$. However, there were only small changes in body proportions, such as RLL:MLL and CDD:TBD (see Fig. 1), at least during the initial halves of all starvation experiments. At $12^{\circ} \mathrm{C}$, for example, both RLL:MLL and CDD:TBD were constant until Day 50 to 60, after which RLL:MLL decreased and CDD:TBD increased, both significantly (Tukey's test, $\mathrm{p}<0.05$ ) (Fig. 4). On the days of $\mathrm{PNR}_{50}$ (33.8, 38.4 and $58.6 \mathrm{~d}$ at 15,12 and $9^{\circ} \mathrm{C}$, respectively, see 'Point of no return' below), the mean DD estimates were $1.36 \pm 0.06,1.69 \pm 0.10$ and $1.65 \pm 0.27 \mathrm{~mm}$, respectively, ca. $30 \%$, on average, reduction compared to mean DD of newly released ephyrae.

\section{Survivorship and median longevity}

Ephyrae did not die at all until Days 44,62 and 92 at 15,12 and $9^{\circ} \mathrm{C}$, respectively, and died off rapidly thereafter (Fig. 5). At $15^{\circ} \mathrm{C}$, the $\mathrm{ML}_{50}$ was recorded on Day 50, the final day of the starvation experiment because of the death of all experimental ephyrae. The $\mathrm{ML}_{50}$ estimates were 70 and $100 \mathrm{~d}$, and the maximum longevities were 80 and $118 \mathrm{~d}$ at 12 and $9^{\circ} \mathrm{C}$, respectively. The relationship between $\mathrm{ML}_{50}(\mathrm{~d})$ and temperature $\left(T,{ }^{\circ} \mathrm{C}\right)$ was expressed by $\mathrm{ML}_{50}=$ $282 \mathrm{e}^{-0.116 T}$.

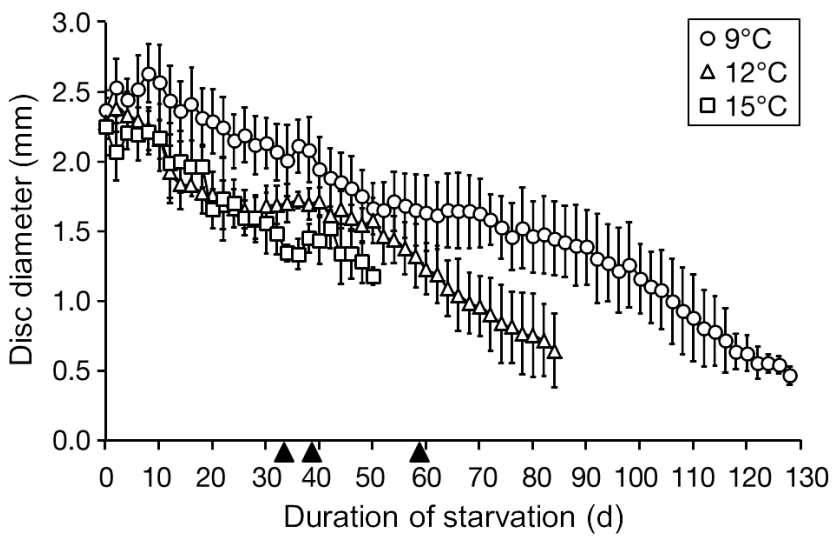

Fig. 3. Change in disc diameter of Aurelia aurita ephyrae kept starved for various periods at 9,12 and $15^{\circ} \mathrm{C}$. Error bars $=\mathrm{SD}$. Filled triangles on $\mathrm{x}$-axis $=$ point of no return $\left(\mathrm{PNR}_{50}\right)$ at 15,12 and $9^{\circ} \mathrm{C}$ from left to right
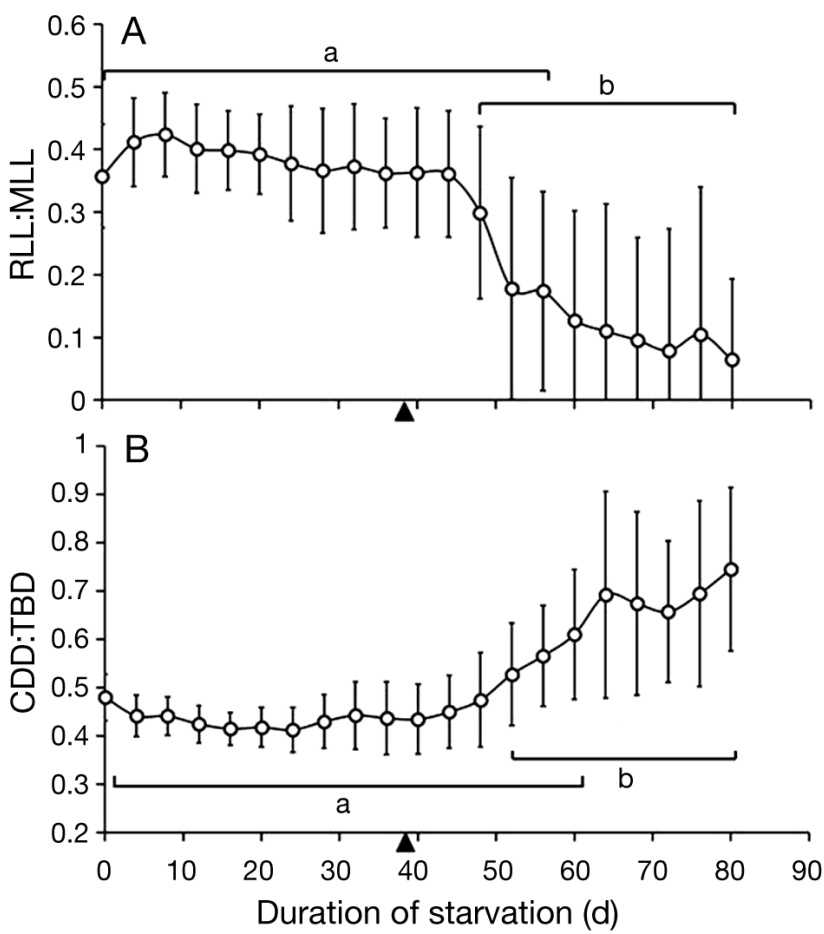

Fig. 4. Changes in body proportions of (A) rhopalial lappet length:marginal lappet length (RLL:MLL) and (B) central disc diameter:total body diameter (CDD:TBD) of Aurelia aurita ephyrae kept starved for various periods at $12^{\circ} \mathrm{C}$. Error bars $=\mathrm{SD}$. Means for periods marked with lowercase ' $a$ ' and 'b' are significantly different. See Fig. 1 for body measurements. Filled triangle on $\mathrm{x}$-axis $=\mathrm{PNR}_{50}$

\section{Point of no return}

Ephyrae fed without prior starvation could swim actively to capture and ingest 5 to 8 Artemia nauplii per day, and they grew to the advanced ephyra stage (mean DD: $4.0 \pm 0.11 \mathrm{~mm}$ ) in averages of 5.0, 4.2 and 


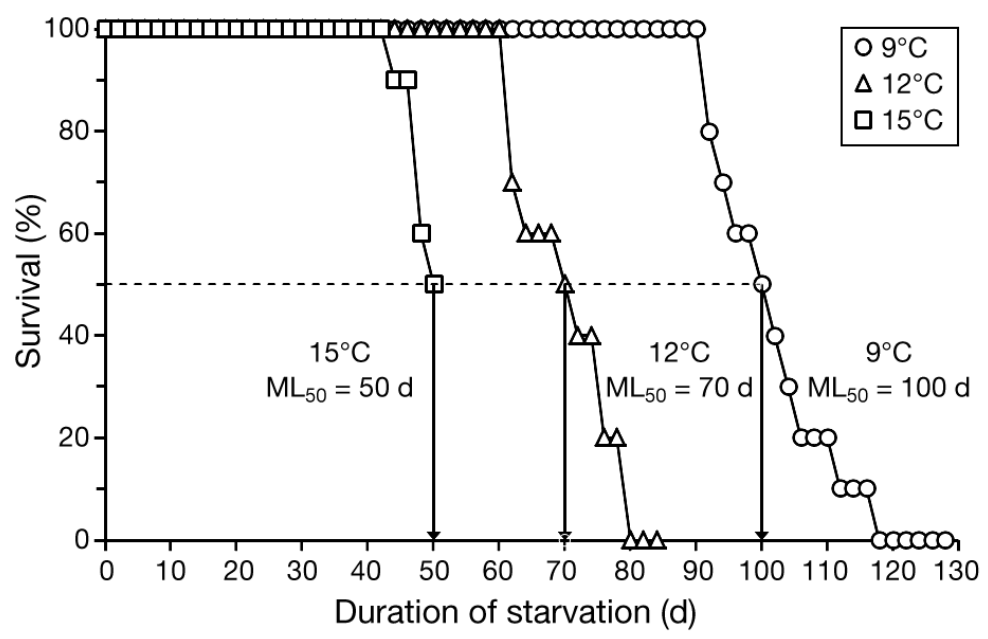

Fig. 5. Survival of Aurelia aurita ephyrae kept starved for various periods at 9,12 and $15^{\circ} \mathrm{C}$. Median longevity ( $\mathrm{ML}_{50}$; arrows) is the starvation period at which $50 \%$ (dashed line) of ephyrae died

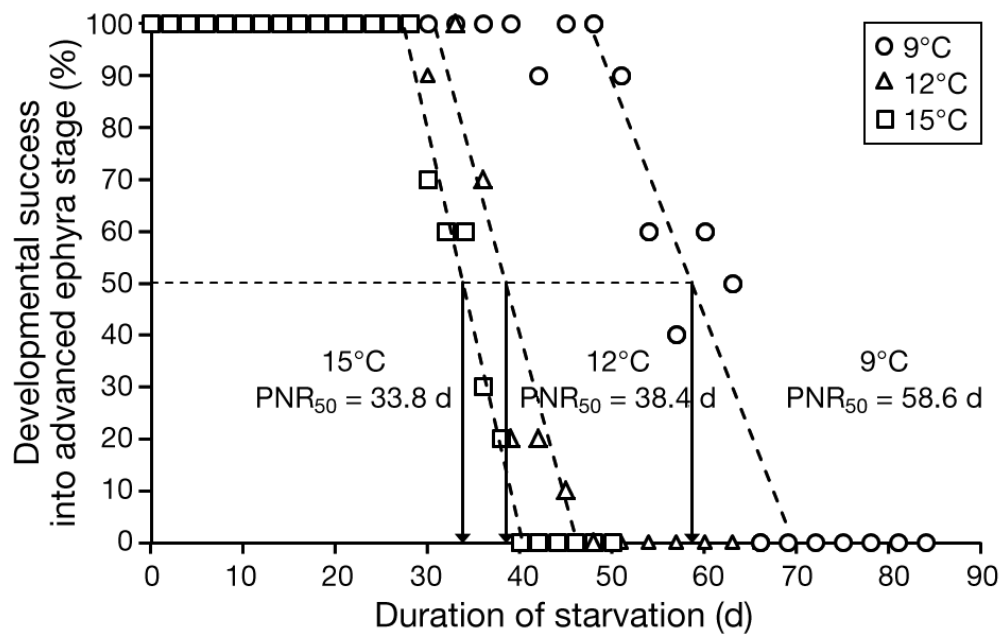

Fig. 6. Success of starved Aurelia aurita ephyrae in developing to become advanced ephyrae when given food after different intervals of starvation. Results shown for ephyrae held at 9,12 and $15^{\circ} \mathrm{C}$. Point of no return $\left(\mathrm{PNR}_{50}\right)$ is the starvation period at which $50 \%$ of ephyrae remain capable of recovering from starvation damage and growing to become advanced ephyrae

$6.0 \mathrm{~d}$ at 15,12 and $9^{\circ} \mathrm{C}$, respectively (see Fig. 7), with significant differences among the groups (1-way ANOVA, $\mathrm{p}<0.05)$. In contrast, with increasing duration of starvation, ephyrae gradually lost their swimming capability, and they could capture fewer Artemia nauplii.

At $15^{\circ} \mathrm{C}$, all ephyrae, which had been starved for $\leq 28 \mathrm{~d}$, could successfully develop to the advanced ephyra stage. When the starvation ran $\geq 30 \mathrm{~d}$, the success declined sharply until Day 40, when no recovery was possible. By fitting a linear regression, the $\mathrm{PNR}_{50}$ was determined to be $33.8 \mathrm{~d}$ (Fig. 6). At $12^{\circ} \mathrm{C}$, nearly $100 \%$ of ephyrae that had been starved for up to Day 36 successfully developed to the advanced ephyra stage. No recovery was possible when starvation was $\geq 48 \mathrm{~d}$. The $\mathrm{PNR}_{50}$ was estimated to be $38.4 \mathrm{~d}$ (Fig. 6). At $9^{\circ} \mathrm{C}$, recovery success was nearly $100 \%$ for ephyrae up to Day 48 , and the $\mathrm{PNR}_{50}$ was $58.6 \mathrm{~d}$ (Fig. 6). The relationship between the $\mathrm{PNR}_{50}(\mathrm{~d})$ and temperature $\left(T,{ }^{\circ} \mathrm{C}\right)$ was expressed by $\mathrm{PNR}_{50}=127 \mathrm{e}^{-0.092 T}$.

The duration needed to reach the advanced ephyra stage after feeding began (DR, d) increased exponentially with increasing initial starvation duration $(D, \mathrm{~d})$ as expressed by $\mathrm{DR}=4.80 \mathrm{e}^{0.040 D}$, $\mathrm{DR}=6.85 \mathrm{e}^{0.021 D}$ and $\mathrm{DR}=7.69 \mathrm{e}^{0.017 D}$ at 15 , 12 and $9^{\circ} \mathrm{C}$, respectively (Fig. 7 ).

\section{Decrease in carbon weight during starvation}

The mode of shrinkage in the DD of starved ephyrae kept collectively in filtered seawater (not shown) was essentially the same as for those kept individually in well plates (Figs. 2 \& 3). Mean carbon and nitrogen weights of newly released ephyrae were $6.6 \pm 0.23$ and $1.5 \pm 0.05 \mu \mathrm{g}$, respectively, without significant differences among the groups (1-way ANOVA, p > $0.05)$, and their carbon contents $(C, \mu \mathrm{g})$ decreased exponentially with starvation duration $(D, \mathrm{~d})$, as expressed by $C=$ $6.7 \mathrm{e}^{-0.026 D}, C=6.4 \mathrm{e}^{-0.019 D}$ and $C=6.8 \mathrm{e}^{-0.017 D}$ at 15,12 and $9^{\circ} \mathrm{C}$, respectively (Fig. $8 \mathrm{~A}$ ). Relative carbon contents in ephyrae at the $\mathrm{PNR}_{50}$ were estimated to be 51,58 and $42 \%$ of the initial contents at 15,12 and $9^{\circ} \mathrm{C}$, respectively. The 2 -way ANOVA showed that carbon:nitrogen $(\mathrm{C}: \mathrm{N})$ ratios $(\mathrm{p}>0.05$ in each case) were not significantly affected by temperature, starvation duration or their interaction. The overall mean C:N ratio was $4.2 \pm 0.14$ (Fig. 8B).

\section{DISCUSSION}

\section{Extraordinary duration to $\mathrm{PNR}_{50}$ in Aurelia aurita ephyrae}

In marine invertebrates and fishes, newly hatched larvae can be regarded as a critical life stage, since 


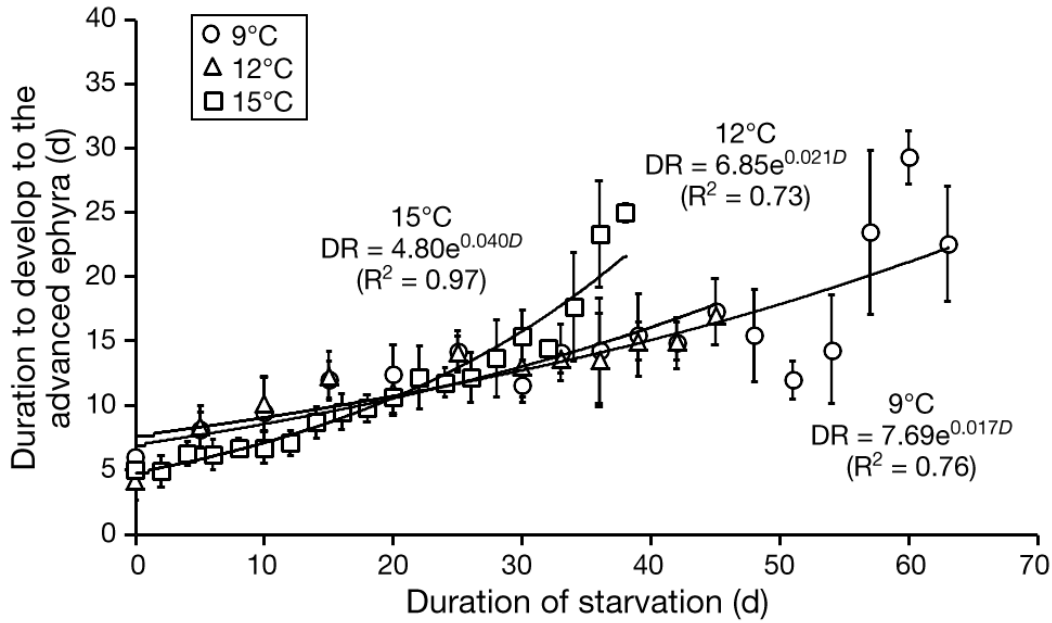

Fig. 7. Relationships between the duration required by initially starved Aurelia aurita ephyrae to develop into advanced ephyrae after feeding began and the durations of starvation at 9, 12 and $15^{\circ} \mathrm{C}$. Error bars $=$ SD. D: initial starvation duration; DR: duration needed to reach advanced ephyra stage after feeding began
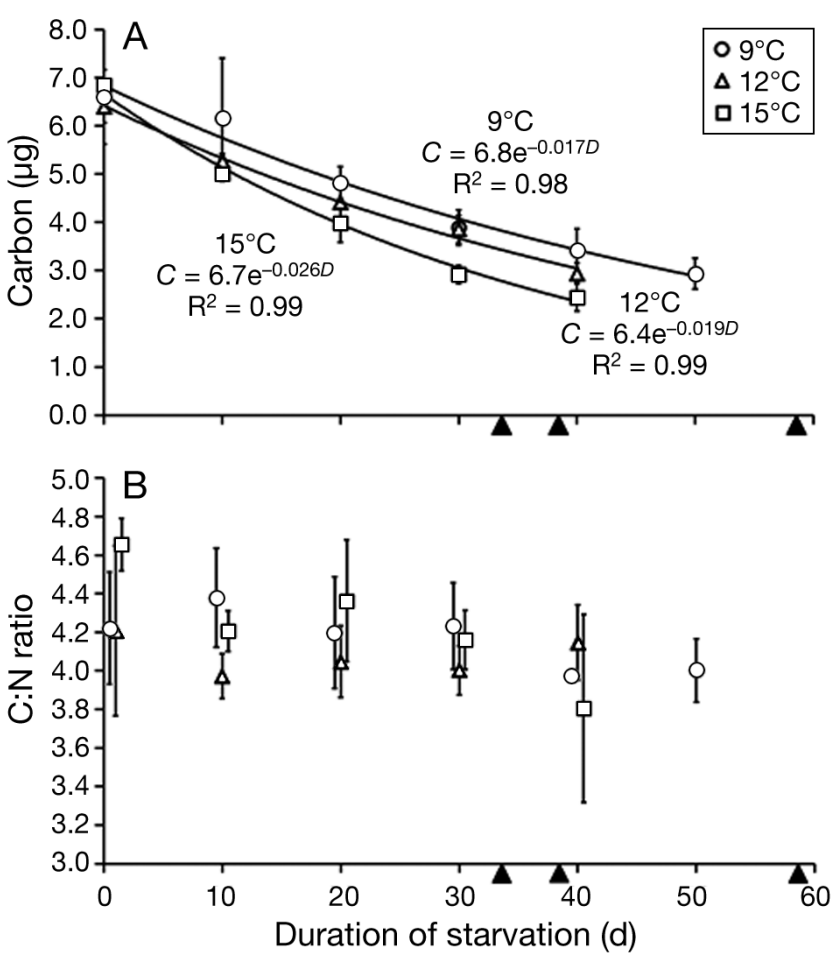

Fig. 8. Change in (A) carbon and (B) carbon:nitrogen (C:N) ratio of Aurelia aurita ephyrae kept starved for various periods at 9,12 and $15^{\circ} \mathrm{C}$. Error bars $=\mathrm{SD}$. Filled triangles on $x$-axis $=\mathrm{PNR}_{50}$ at 15,12 and $9^{\circ} \mathrm{C}$ from left to right. $C$ : carbon contents; $D$ : initial starvation duration

they must start feeding within a limited time, i.e. the PNR, to avoid death by starvation (Blaxter \& Hempel 1963, Bailey \& Houde 1989, Paschke et al. 2004). Hence, the PNR has been studied in many marine animals to evaluate their starvation resistance and to un- derstand the factors affecting recruitment to their post-larval stages. Although scyphozoan ephyrae are derived not from eggs but from strobilating polyps, they likewise have to feed before their PNR to recruit to the medusa population. Previous studies have determined the $\mathrm{PNR}_{50}$ for planktonic larvae of marine animals (e.g. molluscs, crustaceans and fishes, see Table S1 in the Supplement at www. int-res.com/articles/suppl/m510p255_ supp.pdf) and their values are plotted against temperature in Fig. 9. The compiled data show a general trend that the $\mathrm{PNR}_{50}$ is negatively related to temperature in each taxonomic group. At $15^{\circ} \mathrm{C}$, the average $\mathrm{PNR}_{50}$ values estimated for molluscs, crustaceans and fishes are 7.3, 4.8 and $5.8 \mathrm{~d}$, respectively. In marked contrast, the $\mathrm{PNR}_{50}$ for Aurelia aurita ephyrae was $33.8 \mathrm{~d}$, demonstrating that they are capable of enduring extraordinarily long starvation compared to the larvae of other taxa.

This strong starvation resistance of $A$. aurita ephyrae can be attributed to their low metabolic demands, equivalent to 2 to $3 \%$ of body carbon weight $\mathrm{d}^{-1}$ (Fig. 8), relative to copious endogenous carbon reserves (mean: $6.6 \mu \mathrm{g} \mathrm{C}$ ephyra ${ }^{-1}$ ). Assuming that proteins are the major organic constituents and metabolic substrate, as was confirmed by the overall mean $\mathrm{C}: \mathrm{N}$ ratio of 4.2 (Fig. 8), and that the respiratory quotient is 0.8 (Ikeda et al. 2000), the respiration rates indirectly estimated from their carbon weight reductions are $0.40,0.28$ and $0.27 \mu \mathrm{O}_{2}$ ephyra ${ }^{-1} \mathrm{~d}^{-1}$ at 15 , 12 and $9^{\circ} \mathrm{C}$, respectively. This rate at $15^{\circ} \mathrm{C}$ is comparable to the rate $\left(0.42 \mu l \mathrm{O}_{2}\right.$ ephyra $\left.{ }^{-1} \mathrm{~d}^{-1}\right)$ reported by Møller \& Riisgård (2007) and lower than the rate $\left(0.74 \mu \mathrm{O} \mathrm{O}_{2}\right.$ ephyra $\left.^{-1} \mathrm{~d}^{-1}\right)$ determined by Kinoshita et al. (1997). Meanwhile, Acuña et al. (2011) and Pitt et al. (2013) reported that respiration rates of jellyfish are similar to other metazoans (e.g. crustaceans and fish) when scaled to carbon content. Interpolation of $6.6 \mu \mathrm{g} \mathrm{C}$ to the equations presented by Acuña et al. (2011) and Pitt et al. (2013) gives the respiration rates 2.9 and $2.6 \mu \mathrm{O}_{2}$ animal ${ }^{-1} \mathrm{~d}^{-1}$, respectively, values much greater than any mentioned above. Hence, we conclude that the low metabolism per unit carbon weight is specific to the ephyra stage, at least for A. aurita.

Our experiments show that $A$. aurita ephyrae lose ca. $50 \%$ of initial carbon by the time of the $\mathrm{PNR}_{50}$. The loss of body carbon biomass during starvation up to 


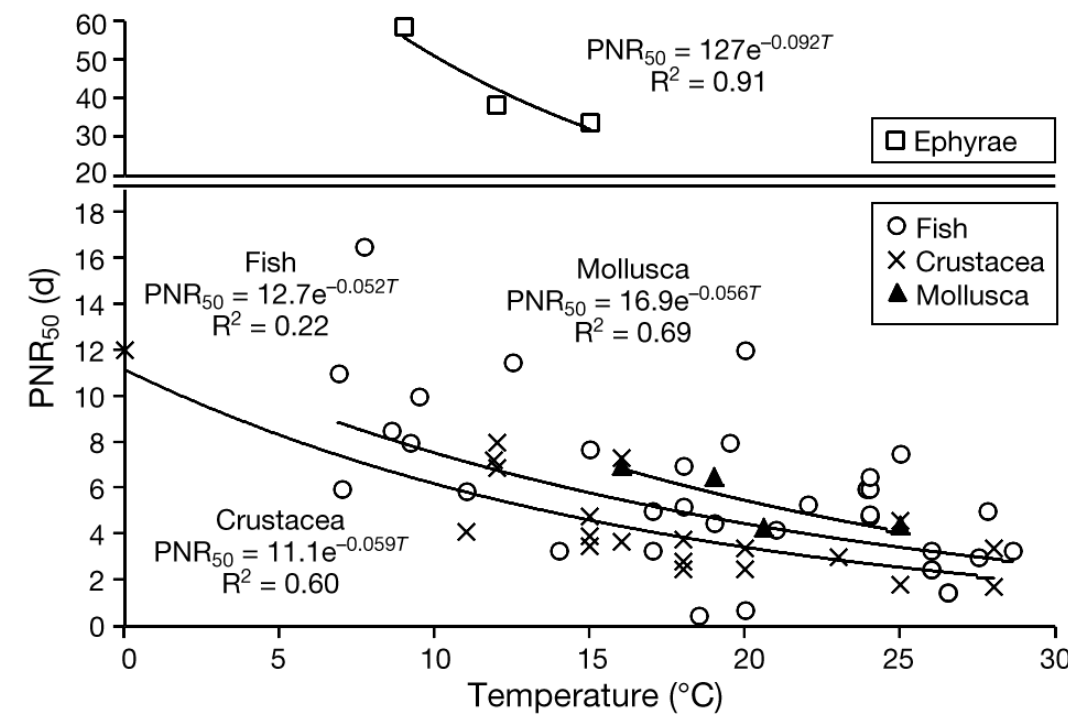

Fig. 9. Relationships between $\mathrm{PNR}_{50}$ and temperature $(T)$ in Aurelia aurita ephyrae, and larvae of molluscs, crustaceans and fishes. Note the different vertical axis scales between $A$. aurita ephyrae and the other taxa. See Table S1 in the Supplement at www.int-res.com/articles/suppl/m510p255_supp.pdf for $\mathrm{PNR}_{50}$ values of each taxon

the $\mathrm{PNR}_{50}$ is, in general, much smaller in other taxa: $16 \%$ loss for Maja brachydactyla (Guerao et al. 2012), 25 to $34 \%$ loss for Carcinus maenas (Dawirs 1987) and $21 \%$ loss for Hyas araneus (Anger \& Dawirs 1982). However, the loss is exceptionally high (44 to $51 \%$ ) for Euphausia superba (Ross \& Quetin 1989). All these facts demonstrate that $A$. aurita ephyrae are capable of recovering from extremely low food conditions that larvae of other taxa may not tolerate.

\section{Ecological significance of long $\mathrm{PNR}_{50}$ in Aurelia aurita ephyrae}

Since an exposure to temperatures lower than $15^{\circ} \mathrm{C}$ is a trigger to induce strobilation (Kakinuma 1962, Han \& Uye 2010), the release of ephyrae of Aurelia aurita is programmed to occur during winter and early spring, in accordance with the annual temperature fluctuation (range: 10 to $28^{\circ} \mathrm{C}$ ) of the Inland Sea of Japan (Uye \& Shimauchi 2005, Thein et al. 2012). A similar seasonal strobilation schedule is observed in many temperate regions (Lucas 2001, Miyake et al. 2002). However, it is difficult to assess the success of feeding and subsequent development of wild ephyrae, since information on their feeding and in situ food supply is inadequate. Although dissolved organic matter was reported to be effective as a nutritional source for ephyrae under starvation conditions, it is a meager one and allows only a slight increase in their survival (Skikne et al. 2009). Phytoplankton are likely a less important food for the net growth of ephyrae compared to zooplankton (Båmstedt et al. 2001). Examination of stomach contents of wild-caught ephyrae and laboratory experiments to test various diets have revealed that the main foods for $A$. aurita ephyrae are small and slow-swimming zooplankton, such as tintinnids, rotifers, nauplii of copepods and barnacles, copepodites and adult copepods, and hydromedusae (Olesen 1995, Sullivan et al. 1997, Ishii et al. 2004). Sullivan et al. (1997) investigated prey capture behavior of $A$. aurita ephyrae in detail and demonstrated that larger prey swimming continuously at low velocity are most vulnerable, suggesting that slowswimming hydromedusae may be more important than fast-swimming copepodite and adult copepods and that continuously swimming rotifers may be more valuable than intermittently swimming copepod nauplii.

During the main season of ephyra release (January to March), mean zooplankton biomass over the entire Inland Sea of Japan is at its annual minimum (ca. 2 and $13 \mathrm{mg} \mathrm{C} \mathrm{m}{ }^{-3}$ for micro- and mesozooplankton, respectively), and zooplankton production rates are also the lowest (ca. 0.5 and $2 \mathrm{mg} \mathrm{C} \mathrm{m}^{-3} \mathrm{~d}^{-1}$, respectively, Uye et al. 1996, Uye \& Shimazu 1997). Rotifers and hydromedusae, which may be suitable food for ephyrae, are never dominant in micro- and mesozooplankton communities. Thus, it is very likely that newly released ephyrae are exposed to severe nutritional stress in this cold season of minimal food abundance. In April, the Inland Sea of Japan significantly warms from the winter temperature minimum (to ca. $15^{\circ} \mathrm{C}$ ), and zooplankton biomass increases to about 3 to $15 \mathrm{mg} \mathrm{C} \mathrm{m}^{-3}$ for micro- and mesozooplankton, respectively. The production rates of those groups in April are on the order of 1 to $4 \mathrm{mg} \mathrm{C} \mathrm{m}^{-3} \mathrm{~d}^{-1}$, respectively (Uye et al. 1996, Uye \& Shimazu 1997). Thus, ephyrae released early in the season (e.g. December to February) would be subjected to more starvation mortality than those released late in the season (e.g. March to April). We conclude that an extremely long $\mathrm{PNR}_{50}$ may be a physiological as well as ecological adaptation allowing $A$. aurita ephyrae to survive the first few months after release, when food supply is generally lowest in many temperate coastal waters. 


\section{Mortality of ephyrae in the field}

It is typical that planktonic larvae of many marine animals in nature are subjected to high mortality because of both food deprivation and predation loss (Bailey \& Houde 1989, Paschke et al. 2004). The fate of Aurelia aurita ephyrae is likely no exception. In the innermost part of Tokyo Bay, Ishii et al. (2004) estimated the mortality from newly released ephyrae to young medusae of the natural $A$. aurita population. Based on the relative abundances of ephyrae in different developmental stages (ages), the cumulative mortality reached ca. $95 \%$ by age $4.6 \mathrm{~d}$ and increased further to ca. $99 \%$ by the young medusa stage ( 20 to $28 \mathrm{~d}$ old). Ishii et al. (2004) suspected that this high mortality was because of predation loss rather than starvation, since the eutrophic Tokyo Bay sustained extremely high zooplankton biomass (mean: $382 \mathrm{mg} \mathrm{C} \mathrm{m}{ }^{-3}$ ) during the study period. Nevertheless, Ishii et al. (2004) failed to determine the actual predators of ephyrae in Tokyo Bay.

We examined the gut contents of possible predators (e.g. hydromedusae and fish larvae) of ephyrae in some 200 plankton samples, which had been taken in winter and spring of 2010 and 2011 in Hiroshima Bay and Harima-Nada, eastern Inland Sea of Japan (Makabe et al. unpubl.), but we could not find explicit evidence of predation. Meanwhile, our laboratory experiments revealed that a scyphomedusa, Chrysaora pacifica, can capture and consume A. aurita ephyrae (Fu et al. unpubl.). So, we speculate that $C$. pacifica medusae, which often co-occur with A. aurita ephyrae in spring in the Inland Sea of Japan (Ueda 2007, Thein et al. 2013), may act as potential predators. Because of much scarcer food abundance in the Inland Sea of Japan, starvation seems to be much more crucial to the survival of ephyrae than in Tokyo Bay, although the evaluation of starvation effect is not easy. Morphological examinations of wild ephyrae with starvation-induced appearances, i.e. significant body size (DD) reduction and morphometric changes (RLL:MLL and CDD:TBD), may be useful for the assessment.

Although A. aurita is undoubtedly the most extensively studied scyphozoan species, the ephyra stage is still greatly understudied. To forecast the possible A. aurita outbreaks prior to the season of medusa blooms, further studies are needed not only to investigate ephyra population dynamics but also to identify causes of death for wild ephyrae, which are prone to food shortage and/or predation loss.
Acknowledgements. We thank Alenka Malej for reading and commenting on an early version of the manuscript and Mariko Takao for assistance with the experiment. Gratitude is extended to 3 anonymous reviewers for critical and useful comments. This study is partially supported by a grant from JSPS (Japan-Slovenia Bilateral Program).

\section{LITERATURE CITED}

Acuña JL, López-Urrutia A, Colin S (2011) Faking giants: the evolution of prey clearance rates in jellyfishes. Science 333:1627-1629

Anger K, Dawirs R (1982) Elemental composition (C, H, N) and energy in growing and starving larvae of Hyas araneus (Decapoda Majidae). Fish Bull 80:419-433

Bailey KM, Houde ED (1989) Predation on eggs and larvae of marine fishes and the recruitment problem. Adv Mar Biol 25:1-83

Båmstedt U, Wild B, Martinussen MB (2001) Significance of food type for growth of ephyrae Aurelia aurita (Scyphozoa). Mar Biol 139:641-650

Blaxter, JHS, Hempel G (1963) The influence of egg size on herring larvae (Clupea harengus L.). J Cons Perm Int Explor Mer 28:211-240

Condon RH, Duarte CM, Pitt KA, Robinson KL and others (2013) Recurrent jellyfish blooms are a consequence of global oscillations. Proc Natl Acad Sci USA 110: 1000-1005

Costello JH, Colin SP (1994) Morphology, fluid motion and predation by the scyphomedusa Aurelia aurita. Mar Biol 121:327-334

> Dawirs RR (1987) Influence of limited growth and elemental composition $(\mathrm{C}, \mathrm{H}, \mathrm{N})$ of Carcinus maenas (Decapoda: Portunidae) larvae reared in the laboratory. Mar Biol 93:543-549

> Dong Z, Liu D, Keesing JK (2010) Jellyfish blooms in China: dominant species, causes and consequences. Mar Pollut Bull 60:954-963

Doyle TK, Hays GC, Harrod C, Houghton DR (2014) Ecological and social benefits of jellyfish. In: Pitt KA, Lucas $\mathrm{CH}$ (eds) Jellyfish blooms. Springer, Heidelberg, p 105-127

> Duarte CM, Pitt KA, Lucas CH, Purcell JE and others (2013) Is global ocean sprawl a cause of jellyfish blooms? Front Ecol Environ 11:91-97

Graham WM (2001) Numerical increases and distributional shifts of Chrysaora quinquecirrha (Desor) and Aurelia aurita (Linne) (Cnidaria: Scyphozoa) in the northern Gulf of Mexico. Hydrobiologia 451:97-111

> Guerao G, Simeó CG, Anger K, Urzua A and others (2012) Nutritional vulnerability of early zoea larvae of crab Maja brachydactyla (Brachyura, Majidae). Aquat Biol 16:253-264

Han CH, Uye S (2010) Combined effects of food supply and temperature on asexual reproduction and somatic growth of polyps of the common jellyfish Aurelia aurita s.l. Plankton Benth Res 5:98-105

> Hansson LJ, Moeslund O, Kiørboe T, Riisgård HU (2005) Clearance rates of jellyfish and their potential predation impact on zooplankton and fish larvae in a neritic ecosystem (Limfjorden, Denmark). Mar Ecol Prog Ser 304:117-131

Ikeda T, Torres JJ, Hernández-León S, Geiger SP (2000) Metabolism. In: Harris RP, Wiebe $\mathrm{PH}$, Lenz J, Skjoldal HR, Huntley M (eds) ICES zooplankton methodology 
manual. Academic Press, San Diego, CA, p 455-532

Ishii H, Kojima S, Tanaka Y (2004) Survivorship and production of Aurelia aurita ephyrae in the innermost part of Tokyo Bay, Japan. Plankton Biol Ecol 51:26-35

Kakinuma Y (1962) On some factors for the differentiations of Cladonema uchidai and Aurelia aurita. Bull Mar Biol Stat Asamushi 11:81-85

Kinoshita J, Hiromi J, Kadota S (1997) Do respiratory metabolic rates of the scyphomedusa Aurelia aurita scale isometrically throughout ontogeny in a sexual generation? Hydrobiologia 347:51-55

Lucas CH (2001) Reproduction and life history strategies of the common jellyfish, Aurelia aurita, in relation to its ambient environment. Hydrobiologia 451:229-246

Lucas CH, Graham WM, Widmer C (2012) Jellyfish life histories: role of polyps in forming and maintaining scyphomedusa populations. Adv Mar Biol 63:133-196

Lucas CH, Gelcich S, Uye S (2014) Living with jellyfish: management and adaptation strategies. In: Pitt KA, Lucas $\mathrm{CH}$ (eds) Jellyfish blooms. Springer, Heidelberg, p 129-150

Lynam CP, Gibbons MJ, Axelsen BE, Sparks CAJ and others (2006) Jellyfish overtake fish in a heavily fished ecosystem. Curr Biol 16:R492-R493

Miyake H, Terazaki M, Kakinuma Y (2002) On the polyps of the common jellyfish Aurelia aurita in Kagoshima Bay. J Oceanogr 58:451-459

Møller LF, Riisgård HU (2007) Respiration in the scyphozoan jellyfish Aurelia aurita and two hydromedusae (Sarsia tubulosa and Aequorea vitrina): effect of size, temperature and growth. Mar Ecol Prog Ser 330:149-154

Olesen NJ (1995) Clearance potential of jellyfish Aurelia aurita, and predation impact on zooplankton in a shallow cove. Mar Ecol Prog Ser 124:63-72

Parsons TR, Lalli CM (2002) Jellyfish population explosions: revisiting a hypothesis of possible causes. La Mer 40:111-121

> Paschke KA, Gebauer P, Buchholz F, Anger K (2004) Seasonal variation in starvation resistance of early larval North Sea shrimp Crangon crangon (Decapoda: Crangonidae). Mar Ecol Prog Ser 279:183-191

Pitt KA, Duarte CM, Lucas CH, Sutherland KR and others (2013) Jellyfish body plans provide allometric advantages beyond low carbon content. PLoS ONE 8:e72683

Purcell JE (1997) Pelagic cnidarians and ctenophores as predators: selective predation, feeding rates, and effects on prey populations. Ann Inst Oceanogr 73:125-137

Purcell JE (2012) Jellyfish and ctenophore blooms coincide with human proliferations and environmental perturbations. Annu Rev Mar Sci 4:209-235

Purcell JE, Uye S, Lo WT (2007) Anthropogenic causes of jellyfish blooms and their direct consequences for humans: a review. Mar Ecol Prog Ser 350:153-174

Submitted: October 30, 2013; Accepted: March 24, 2014
Richardson AJ, Bakun A, Hays GC, Gibbons MJ (2009) The jellyfish joyride: causes, consequences and management responses to a more gelatinous future. Trends Ecol Evol 24:312-322

> Ross R, Quetin L (1989) Energetic cost to develop to the first feeding stage of Euphausia superba Dana and the effect of delays in food availability. J Exp Mar Biol Ecol 133:103-127

Skikne SA, Sherlock RE, Robinson BH (2009) Uptake of dissolved organic matter by ephyrae of two species of scyphomedusae. J Plankton Res 31:1563-1570

Straehler-Pohl I, Jarms G (2010) Identification key for young ephyrae: a first step for early detection of jellyfish blooms. Hydrobiologia 645:3-21

Sullivan BK, Suchman CL, Costello JH (1997) Mechanics of prey selection by ephyrae of the scyphomedusa Aurelia aurita. Mar Biol 130:213-222

> Thein H, Ikeda H, Uye S (2012) The potential role of podocysts in perpetuation of the common jellyfish Aurelia aurita s.l. (Cnidaria: Scyphozoa) in anthropogenically perturbed coastal waters. Hydrobiologia 690:157-167

> Thein H, Ikeda H, Uye S (2013) Ecophysiological characteristics of podocysts in Chrysaora pacifica (Goette) and Cyanea nozakii Kishinouye (Cnidaria: Scyphozoa: Semaeostomeae): effects of environmental factors on their production, dormancy and excystment. J Exp Mar Biol Ecol 446:151-158

Toyokawa M, Furota T, Terazaki M (2000) Life history and seasonal abundance of Aurelia aurita medusae in Tokyo Bay, Japan. Plankton Biol Ecol 47:48-58

Ueda Y (2007) Blooms of two jellyfish Chrysaora pacifica and Aurelia aurita in coastal waters off Tokushima Prefecture, Shikoku. Tokushima Pref Fish Exp Stn Newsl No. 62 (in Japanese)

- Uye S (2011) Human forcing of the copepod-fish-jellyfish triangular trophic relationship. Hydrobiologia 666:71-83

Uye S, Shimauchi H (2005) Population biomass, feeding, respiration and growth rates, and carbon budget of the scyphomedusa Aurelia aurita in the Inland Sea of Japan. J Plankton Res 27:237-248

Uye S, Shimazu T (1997) Geographical and seasonal variations in abundance, biomass and estimated production rates of meso- and macrozooplankton in the Inland Sea of Japan. J Oceanogr 53:529-538

Uye S, Ueta Y (2004) Recent increase of jellyfish populations and their nuisance to fisheries in the Inland Sea of Japan. Bull Jpn Soc Fish Oceanogr 68:9-19 (in Japanese with English abstract)

Uye S, Nagano N, Tamaki H (1996) Geographical and seasonal variations in abundance, biomass and estimated production rates of microzooplankton in the Inland Sea of Japan. J Oceanogr 52:689-703

Proofs received from author(s): June 9, 2014 